JeMAS 11 (1) (2015) 16-24
Jitt://journal.unnes.ac.id/nju/index.php/kemas

\title{
PENGARUH MEDIA FILM TERHADAP SIKAP IBU PADA DETEKSI DINI KANKER SERVIKS
}

\author{
Sri Mulyati ${ }^{1 凶}$, Oki Suwarsa ${ }^{2}$, Insi Farisa Desy Arya ${ }^{2}$ \\ ${ }^{1}$ Poltekkes Kemenkes Bandung, Jl. Sederhana No.2 Bandung \\ ${ }^{2}$ Fakultas Kedokteran Universitas Padjajaran, Jl.Eijkman No. 38 Bandung
}

\begin{tabular}{l} 
Info Artikel \\
\hline Sejarah Artikel: \\
Diterima 25 Maret 2015 \\
Disetujui 6 Juli 2015 \\
Dipublikasikan Juli 2015 \\
\hline Keywords: \\
Attitude; Movie; VIA \\
\hline DOI \\
http://dx.doi.org/10.15294/ \\
kemas.v11i1.3401
\end{tabular}

\begin{abstract}
Abstrak
Salah satu cara yang praktis dan murah untuk mencegah terjadinya kanker serviks adalah melalui tes Inspeksi Visual Asam Asetat (IVA). Upaya untuk mempengaruhi sikap ibu pada tes IVA adalah pendidikan kesehatan melalui film. Tujuan penelitian ini adalah untuk mengetahui pengaruh pendidikan kesehatan melalui film terhadap sikap ibu pada tes IVA. Penelitian ini dilakukan pada tahun 2014. Rancangan penelitian ini adalah non randomized within group design. Pengambilan sampel dilakukan dengan teknik consecutive sampling pada 60 responden. Analisis bivariat yang digunakan pada penelitian ini adalah uji wilcoxon. Hasil penelitian menunjukkan terdapat pengaruh positif pendidikan kesehatan melalui film terhadap sikap ibu $(\mathrm{P}<0,05)$ dengan peningkatan median (rentang) skor sikap dari 44,23 (19,23-75) menjadi 78,85 (25-94,23). Kesimpulan penelitian ini adalah terdapat pengaruh positif pendidikan kesehatan melalui film terhadap sikap ibu.
\end{abstract}

\section{THE EFFECT OF MOVIE MEDIA ON ATTITUDE OF WOMEN IN THE CERVICAL CANCER EARLY DETECTION}

\begin{abstract}
The Visual Inspection with Acetic Acid (VIA) test is a practical and cheaper way to prevent cervical cancer. One way to influence attitude in VIA test is health education based on the movie. The purpose of this study was to determine the effect of health education based on the movie on the attitude, of women in VIA test. The study conducted at 2014. The study design was nonrandomized within group design. The sampling technique was consecutive sampling technique on 60 respondents. The data analysis employed bivariable analysis with wilcoxon test. This study shows there was a significant positive effect of the health education based on the movie on the mother's attitude $(P<0.05)$ with median and range attitude score increasing from 44.23 (19.23-75) to 78.85(25-94.23). This study concludes that there is significant positive effect of the health education based on the movie on attitude.
\end{abstract}

(c) 2015 Universitas Negeri Semarang 


\section{Pendahuluan}

Kanker serviks adalah suatu keganasan yang sering menyebabkan kematian yang disebabkan oleh virus HPV (Human Papilloma Virus). Menurut International Agency For Research On Cancer (IARC) pada tahun 2012, kanker serviks merupakan jenis kanker dengan insiden ketiga terbanyak di dunia dari seluruh jenis kanker pada wanita yaitu sekitar 7,9\% dan yang meninggal akibat kanker serviks sekitar 7,5\% (IARCH, 2012). Insiden kanker serviks $90 \%$ terjadi di negara berkembang. Indonesia merupakan negara berkembang dengan jumlah penderitakanker serviks nomor enam terbanyak di Asia Diperkirakan insiden penyakit ini adalah sekitar 17 per 100.000 penduduk (Ngan, 2011). Tingginya angka kematian akibat kanker serviks di Indonesia disebabkan karena 95\% wanita tidak menjalani pemeriksaan secara dini sehingga menyebabkan keterlambatan diagnosis dari kanker serviks dan menurunkan harapan hidup wanita. Berdasarkan hasil penelitian probabilitas ketahanan hidup 5 tahun pasien kanker serviks dengan stadium 1 sekitar 70\%, stadium II sekitar 37,4\%, stadium III sekitar $12,4 \%$ dan stadium IV pada tahun kedua sudah menjadi 0\% (Gayatri, 2005).

Kejadian kanker serviks dapat dicegah dengan deteksi dini lesi prakanker. Deteksi dini lesi prakanker dapat mencegah lesi prakanker tidak berlanjut menjadi kanker leher rahim jika segera dilakukan pengobatan. Hal ini terbukti di negara-negara maju yang telah mengalami penurunan insiden kanker serviks. Contohnya di Amerika Serikat, dalam 50 tahun terakhir insidens kanker serviks turun sekitar 70\% yang dimungkinkan karena adanya program deteksi dini dan tatalaksana yang baik. Hal ini sejalan pula dengan penelitian Peirson (2013), yang menjalani systematic review dari tahun 1995 sampai 2012. Hasil penelitian membuktikan bahwa deteksi dini lesi prakanker dapat menurunkan insiden kanker serviks dan menurunkan angka kematian yang disebabkan oleh kanker serviks.

Salah satu deteksi dini lesi prakanker antara lain melalui Tes Inspeksi Visual Asam Asetat. Tes Inspeksi Visual Asam Asetat (Tes IVA) adalah suatu metode skrining kanker serviks dengan menggunakan larutan asam asetat 3-5\% pada serviks dan melihat perubahan warna yang terjadi setelah dilakukan olesan yang bertujuan untuk melihat adanya sel serviks yang mengalami displasia. Metode inspeksi visual lebih mudah, lebih sederhana, dan lebih mampu laksana. Metode ini dapat dilakukan di semua tingkat pelayanan kesehatan, oleh petugas kesehatan yang terlatih termasuk bidan (Ngan, 2011). Penelitian membuktikan bahwa tes IVA memiliki tingkat sensitivitas dan spesifisitas yang cukup tinggi untuk digunakan sebagai metode penapisan lesi prakanker. Hasil penelitian Wiyono (2008), di Semarang pada 120 wanita usia subur menunjukkan hasil sensitivitas tes IVA adalah $84 \%$ dan spesifisitas $89 \%$. Hal ini sesuai pula dengan penelitian Arbyn (2008) pada 58.000 wanita di India dan Afrika dengan hasil penelitian yang menunjukkan sensitivitas tes IVA adalah 83\% dan spesifisitas tes IVA adalah $85 \%$.

Program tes IVA melalui program See and Treat di Kabupaten Karawang dimulai pada tahun 2007 sampai dengan 2012. Target cakupan dari program tes IVA di Kabupaten Karawang adalah $80 \%$ dari target sasaran akan tetapi target 5 tahun dari tahun 2007 sampai dengan 2012 hanya mencapai 40\%, pada tahun 2013 cakupan tes IVA hanya mencapai 20,6\% (Dinas Kesehatan Kab. Karawang, 2013). Banyak faktor yang berhubungan dengan keikutsertaan ibu untuk ikut serta pada tes IVA di antaranya adalah faktor perilaku yang dipengaruhi oleh niat dan sikap ibu. Berdasarkan hasil penelitian menunjukan bahwa wanita yang bersikap baik berpotensi lebih besar menjalani pemeriksaan IVA jika dibandingkan dengan wanita yang bersikap kurang baik. Hasil penelitian menunjukkan bahwa persepsi yang salah (seperti tidak perlu memeriksakan diri karena tidak adanya gejala kanker, deteksi dini kanker serviks hanya untuk wanita yang berperilaku seksual yang tidak aman) dapat mempengaruhi keikutsertaan deteksi dini kanker serviks (Ackerson, 2007). Hal ini sesuai dengan hasil wawancara pada study pendahuluan dengan Kepala Bagian Penyakit Tidak Menular Dinas Kesehatan Kabupaten Karawang pada Bulan Maret 2014, kendala program tes IVA di antaranya adalah sikap ibu yang tidak mau untuk memeriksakan diri karena merasa malu, merasa tidak ada gejala kanker leher rahim, dan merasa tidak 
perlu untuk memeriksakan diri.

Salah satu upaya untuk menciptakan perilaku masyarakat yang kondusif untuk kesehatan adalah melalui pendidikan kesehatan yaitu kegiatan untuk meningkatkan pengetahuan, sikap dan perilaku masyarakat. Pendidikan kesehatan yang telah dilakukan pada program tes IVA di Kabupaten Karawang pada umumnya adalah metode ceramah tanya jawab dengan media lembar balik. Penelitian di 12 Puskesmas Kabupaten Karawang pada tahun 2009 yang bertujuan untuk mengevaluasi program tes IVA dari tahun 2007 sampai dengan 2008 memberikan rekomendasi agar media pendidikan kesehatan lebih ditingkatkan untuk meningkatkan cakupan program tes IVA (Ghazali, 2009).

Pada pendidikan kesehatan masyarakat dikenal media pendidikan di antaranya film. Film merupakan media audiovisual yang sangat efektif sebab karakteristik film yang dapat menyajikan gambar bergerak disamping suara yang menyertainya yang dapat mempengaruhi sikap seseorang (Nurseto, 2011). Hasil Penelitian menunjukan hasil bahwa pemberian pendidikan kesehatan melalui media audiovisual dapat mempengaruhi sikap terhadap program kesehatan (Poureslami, 2007). Berdasarkan latar belakang penelitian tersebut peneliti tertarik untuk meneliti tentang pengaruh positif pendidikan kesehatan melalui film terhadap sikap ibu menjalani deteksi dini kanker serviks dengan tes IVA di Kabupaten Karawang. Penelitian yang serupa dengan penelitian ini adalah penelitian mengenai pendidikan kesehatan pada kelompok ibu PKK (Pembinaan Kesejahteraan Keluarga) dalam meningkatkan pemahaman masyarakat untuk mencegah penyakit kanker serviks (Sugiarsi, 2011). Akan tetapi pada penelitian tersebut pendidikan kesehatan yang dilakukan tidak melalui film sehingga terdapat perbedaan antara penelitian ini dengan penelitian tersebut yaitu pada variabel yang diteliti.

\section{Metode}

Penelitian ini telah dilakukan pada bulan September 2014 s/d Desember 2014 di Kecamatan Batujaya dan Rengasdengklok Kabupaten Karawang. Sampel pada penelitian ini adalah WUS di Kabupaten Karawang yang memenuhi kriteria inklusi dan eksklusi. Besar sampel dihitung berdasarkan rumus besar sampel yaitu:

$$
\mathrm{n}=\underline{\mathrm{Z}}_{\mathrm{a}} \frac{\mathrm{X} \mathrm{S}}{\mathrm{d}}
$$

Keterangan:

$\mathrm{Z}_{\mathrm{a}}=$ Deviat baku alfa

$\mathrm{S}=$ Simpang baku variabel yang diteliti

$\mathrm{d}=$ Presisi

Kesalahan tipe I ditetapkan 5\%, hipotesis dua arah, maka $Z a=1,65$ (taraf kepercayaan 95\%). Simpang baku ditetapkan berdasarkan penelitian sebelumnya (Krawczyk, 2012). Simpang baku yang ditetapkan adalah 4 dan presisi adalah 1. Berdasarkan hasil penghitungan didapatkan jumlah sampel minimal sebesar 44 orang. Pada penelitian ini jumlah sampel ditingkatkan menjadi 60 orang.

Program tes IVA telah dikembangkan di 20 Puskesmas di wilayah Kabupaten Karawang atau di 19 Kecamatan. Pada penelitian ini dipilih Kecamatan dengan cakupan IVA terendah yaitu Kecamatan Batu Jaya sebanyak 30 orang dan Kecamatan Rengasdengklok Kabupaten Karawang sebanyak 30 orang. Sampel dipilih secara consecutive sampling, sampel dipilih yang memenuhi kriteria penelitian sampai jumlah sampel terpenuhi. Kriteria inklusi pada penelitian ini adalah WUS usia 15-50 tahun, sudah menikah, belum menopause, belum pernah menjalani tes IVA atau tes Pap Smear, belum pernah menjalani histerektomi total (pengangkatan rahim total), bersedia menjadi subjek penelitian. Sedangkan kriteria eksklusi penelitian ini adalah diketahui menderita kanker serviks.

Penelitian ini menggunakan desain nonrandomized control trial dengan rancangan nonrandomized within group design atau prepost test one group untuk mencari pengaruh atau efek perlakuan. Rancangan ini hanya menggunakan satu kelompok subjek dan pengukuran dilakukan sebelum dan setelah perlakuan. Setiap responden penelitian menjadi kontrol terhadap dirinya sendiri. Pada penelitian ini responden diberikan pendidikan kesehatan melalui film secara berkelompok pada minggu pertama dan kedua, selain itu masing-masing responden juga diberikan DVD 
dari film tersebut. Pengukuran sikap ibu sebagai variabel terikat diukur sebelum perlakuan (pretest) pada minggu pertama. Pengukuran posttest sikap dilakukan pada minggu kedua.

Instrumen pada penelitian ini berupa kuesioner dan film. Kuesioner yang diberikan secara langsung oleh peneliti. Kuesioner yang dipakai untuk pengukuran sikap adalah kuesioner yang diadaptasi dari penelitian Myriam Leyva yang berdasarkan TRA yang terdiri dari 13 pernyataan (Leyva, 2006). Kuisioner telah diuji validitas dan reabilitas pada 30 responden. Sedangkan. Instrumen untuk mengukur keikutsertaan pelayanan IVA dengan menggunakan lembar observasi catatan pelayanan tes IVA. Pengujian validitas dan reabilitas kuisioner dilakukan pada 30 orang responden di Kecamatan Klari Kabupaten Karawang.

Film yang digunakan pada penelitian ini adalah film yang berisi film cerita dan animasi yang dibuat dengan mengacu pada buku Panduan Kanker Serviks dari Kemenkes RI Tahun 2009. Pengujian validitas isi film pada penelitian ini telah dilakukan dengan cara konsultasi isi film kepada Kepala Bagian Penyakit Tidak Menular di Dinas Kesehatan Kabupaten Karawang.

Pada penelitian ini rancangan analisis data yang dilakukan dengan menggunakan bantuan program komputerisasi meliputi analisis deskriptif (analisis univariat) dan bivariat. Analisis univariat dilakukan untuk mendeskripsikan karakteristik masing-masing variabel yang diteliti. Pada penelitian ini analisis dilakukan untuk mendeskripsikan tiap variabel yang diukur meliputi variabel bebas dan variabel terikat. Ukuran statistik yang akan digunakan pada penelitian ini adalah distribusi frekuensi dan proporsi masing-masing variabel yang diteliti. Sikap responden diukur berdasarkan skor sikap yang ditansformasikan menjadi skala interval berdasarkan rumus skala 100. Normalitas distribusi data dianalisis dengan metode analitik Kolmogorov-Smirnov karena jumlah sampel lebih dari 50. Jika hasil uji normalitas diperoleh $\mathrm{P}>0,05$ maka sebaran data disebut normal. Analisis bivariat untuk menguji pengaruh perlakuan yang telah diberikan yaitu pengaruh pendidikan kesehatan melalui film terhadap sikap ibu pada tes IVA menggunakan uji $\mathrm{T}$ berpasangan jika data berdistribusi normal atau uji wilcoxon jika data berdistribusi tidak normal. Pengolahan data tersebut dengan menggunakan SPSS Versi 12.

\section{Hasil dan Pembahasan}

Berdasarkan tabel satu terlihat bahwa pada penelitian ini sebagian besar responden yaitu setengah dari kelompok responden Tabel 1. Deskripsi Karakteristik Responden

\begin{tabular}{ll}
\hline Karakteristik & \multicolumn{1}{c}{$\mathrm{n}=60(\%)$} \\
\hline $\begin{array}{l}\text { 1. Umur } \\
\text { Median (Rentang) }\end{array}$ & \multicolumn{1}{c}{$29,50(18-48)$} \\
15-29 tahun & $30(50,0 \%)$ \\
30-50 tahun & $30(50,0 \%)$ \\
2. Pendidikan & \\
SD & $44(73,3 \%)$ \\
SMP & $12(20,0 \%)$ \\
Z SMA & $4(6,7 \%)$ \\
3. Pekerjaan & \\
Tidak Bekerja & $56(93,3 \%)$ \\
Bekerja & $4(6,7 \%)$ \\
4. Paritas & \\
$0-2$ & $36(60 \%)$ \\
$\geq 3$ & $24(40 \%)$
\end{tabular}

Sumber : Data Primer

berumur 30-50 tahun, hampir duapertiga dari kelompok responden memiliki tingkat pendidikan SD, hampir seluruh responden merupakan ibu yang tidak bekerja dan lebih dari setengah kelompok responden memiliki paritas 0-2.

Pada tabel 2 dapat diketahui bahwa nilai median dan rentang dari skor sikap setelah perlakuan menjadilebih tinggidaripadasebelum

Tabel 2. Perbandingan Skor Sikap Pada Tes IVA Sebelum dan Setelah perlakuan $(n=60)$.

\begin{tabular}{l|l|l|l|l}
\hline Variabel & $\begin{array}{l}\text { Sebelum perlakuan } \\
(\mathrm{n}=60)\end{array}$ & $\begin{array}{l}\text { Sesudah Perlakuan } \\
(\mathrm{n}=60)\end{array}$ & Nilai P & $\begin{array}{l}\text { Peningkatan } \\
(\%)\end{array}$ \\
\hline $\begin{array}{l}\text { Skor sikap } \\
\text { Median (Rentang) }\end{array}$ & $44,23(19,23-75)$ & $78,85(25-94,23)$ & $<0,01^{\star}$ & $78,27 \%^{* \star}$ \\
\hline
\end{tabular}


perlakuan. Terdapat persentase peningkatan hampir 80\%. Berdasarkan hasil uji statistik nilai $\mathrm{P}<0,05$ sehingga terdapat perbedaan skor sikap pada kelompok responden sebelum perlakuan dan setelah perlakuan. Oleh karena itu dapat diasumsikan bahwa pendidikan kesehatan melalui film berpengaruh terhadap sikap ibu.

Faktor yang dapat mempengaruhi keberhasilan pendidikan kesehatan selain media adalah faktor karakteristik responden yang terdiri dari umur, pendidikan, pekerjaan (Notoatmodjo, 2007). Pada penelitian ini setengah dari kelompok responden berumur 30-50 tahun. Responden yang berumur lebih dari 30 tahun memiliki kemungkinan memiliki lesi prakanker yang lebih tinggi dibandingkan usia dibawah 30 tahun sehingga responden pada usia tersebut akan merasa lebih penting untuk melakukan tes IVA (Lu-lu, 2012). Selain itu umur dapat mempengaruhi daya tangkap dan pola pikir seseorang. Semakin bertambah usia seseorang maka akan semakin berkembang pula daya tangkap dan pola pikirnya. Selain itu semakin cukup umur maka seseorang akan lebih dewasa dan mudah percaya sehingga informasi tentang kanker serviks dan pentingnya tes IVA akan lebih mudah diterima (Notoatmodjo, 2007).

Berdasarkan hasil penelitian diperoleh hasil bahwa sebagian besar responden yaitu hampir duapertiga dari kelompok responden memiliki tingkat pendidikan SD, Keberhasilan pendidikan kesehatan dapat dipengaruhi oleh tingkat pendidikan karena pendidikan dapat mempengaruhi cara pandang seseorang terhadap informasi baru yang diterimanya. Semakin tinggi tingkat pendidikannya, semakin mudah seseorang menerima informasi yang didapatkannya (Notoatmodjo, 2007). Akan tetapi teori ini tidak sesuai dengan hasil penelitian yang menyatakan bahwa tidak ditemukan hubungan positif antara tingkat pendidikan dan perilaku seseorang setelah responden tersebut menerima pendidikan kesehatan (Putri, 2009). Hal ini sesuai dengan hasil penelitian ini yang menunjukan hasil banyak responden berpendidikan rendah tapi $60 \%$ responden ikut serta pada tes IVA. Hal tersebut dapat diakibatkan oleh penyerapan informasi dengan pendidikan kesehatan melalui film merupakan metode yang efektif bagi masyarakat baik yang berpendidikan rendah maupun tinggi. Hal ini sesuai dengan teori yang menyebutkan bahwa semua peserta didik dapat belajar dari film baik yang pandai maupun yang kurang pandai. Selain itu dapat pula diakibatkan karena adanya dukungan sosial yaitu setelah responden menerima informasi kesehatan, banyak responden yang berpendidikan rendah tapi memiliki perilaku yang baik. Hal tersebut dapat diakibatkan karena faktor lain yang mempengaruhi perilaku tersebut misalnya faktor dukungan sosial (Putri, 2009).

Hasil penelitian yang ditunjukan menyebutkan bahwa hampir seluruh responden tidak bekerja. Pekerjaan seseorang dapat mempengaruhi penghasilan dan pendapatan. Semakin tinggi ekonomi seseorang, semakin mudah pula upaya menerima informasi baru sehingga akhirnya dapat mempengaruhi hasil dari pendidikan kesehatan tentang kanker serviks dan tes IVA (Notoatmodjo, 2007). Pada penelitian ini walaupun sebagian besar responden tidak bekerja akan tetapi hasil penelitian menunjukan terdapat peningkatan pada sikap, niat dan keikutsertaan ibu pada tes IVA. Hal ini dimungkinkan adanya faktor lain yang mempengaruhinya misalnya faktor dukungan sosial. Selain karakteristik pekerjaan, terlihat juga bahwa responden memiliki paritas 0-2 (60\%) dan paritas $\geq 3$ (40\%). Responden yang telah melahirkan memiliki resiko untuk memiliki lesi prakanker, menurut hasil penelitian ibu dengan paritas $\geq 3$ lebih beresiko memiliki lesi prakanker sehingga responden pada usia tersebut akan merasa lebih penting untuk melakukan tes IVA (Lu-Lu, 2012).

Pada penelitian ini, seluruh responden penelitian adalah wanita usia subur yang memenuhi syarat untuk melakukan tes IVA akan tetapi mereka belum pernah melakukan tes IVA. Banyak faktor yang dapat mempengaruhi perilaku tersebut, diantaranya adalah sikap ibu. Sikap merupakan reaksi atau respon yang masih tertutup dari seseorang terhadap suatu stimulus atau objek. Sikap adalah perasaan, pikiran dan kecenderungan seseorang yang kurang lebih bersifat permanen mengenai aspekaspek tertentu dalam lingkungannya. Sikap merupakan kecondongan evaluatif terhadap suatu stimulus atau objek yang berdampak 
pada bagaimana seseorang berhadapan dengan objek tersebut. Menurut Fishbein sikap adalah respon afektif atau penilaian positif-negatif seseorang terhadap suatu objek. Sikap berasal dari keyakinan terhadap perilaku (behavioral beliefs) dan evaluasi seseorang terhadap konsekuensi yang akan ditanggung (Montano, 2008).

Pada penelitian ini telah dilakukan pemberian pendidikan kesehatan pada responden. Upaya tersebut sesuai dengan teori yang menyebutkan bahwa salah satu upaya yang dapat dilakukan untuk mempengaruhi sikap ibu pada perilaku kesehatan adalah melalui pendidikan kesehatan (Notoatmodjo, 2007). Hasil analisis menunjukan bahwa pemberian pendidikan kesehatan melalui film berpengaruh terhadap sikap ibu pada tes IVA. Setelah diberikan pendidikan kesehatan melalui film, median skor sikap responden meningkat dari 44,23 menjadi 78,85. Persentase peningkatan menunjukan terjadi peningkatan sebesar 78,27\%. Hasil uji statistik menunjukan terdapat perbedaan bermakna antara sebelum pemberian pendidikan kesehatan melalui film dan setelah pemberian pendidikan kesehatan melalui film $(\mathrm{P}<0,05)$. Berdasarkan hasil penelitian tersebut dapat diasumsikan bahwa pemberian pendidikan kesehatan melalui film berpengaruh secara signifikan terhadap sikap ibu pada tes IVA. Hasil penelitian tersebut sesuai dengan penelitian Lestari Handayani yang menunjukan hasil bahwa terdapat pengaruh yang signifikan dari pendidikan kesehatan melalui media audiovisual terhadap perubahan sikap seseorang (nilai $\mathrm{p}<0,05$ ). Pada penelitian tersebut menyatakan bahwa media audiovisual merupakan media yang efektif yang dapat meningkatkan sikap seseorang (Handayani, 2010).

Media audiovisual merupakan media yang efektif karena media audiovisual dapat memberikan informasi secara jelas melalui gambar dan suara. Hal ini sejalan dengan teori yang menyebutkan bahwa film sebagai suatu media audiovisual memungkinkan sinyal audio dapat dikombinasikan dengan gambar bergerak. Film dapat mempermudah penerimaan informasi. tingkat retensi (daya serap dan daya ingat) peserta didik terhadap materi pembelajaran dapat meningkat secara signifikan jika proses perolehan informasi melalui indera pendengaran dan penglihatan (visualisasi). Menurut penelitian, indera paling banyak menyalurkan pengetahuan ke dalam otak adalah mata. Kurang lebih $75 \%$ sampai $87 \%$ dari pengetahuan manusia diperoleh melalui mata. Kurang lebih 13\% sampai 25\% dari pengetahuan diperoleh melalui indera lain. Informasi merupakan kondisi pertama untuk suatu sikap. Bila berdasarkan informasi itu timbul perasaan positif atau negatif terhadap objek dan menimbulkan kecenderungan untuk bertingkahlaku tertentu maka terjadilah sikap (Notoatmodjo, 2007). Hal ini sesuai dengan hasil penelitian Musfiroh (2014), yang menyatakan bahwa tindakan pemberian pendidikan kesehatan dapat memperjelas informasi sehingga akhirnya dapat meningkatkan sikap positif seseorang.

Selain film dapat mempermudah penyerapan informasi, film sebagai media pembelajaran juga dapat berfungsi afektif yaitu dapat menggugah perasaan, emosi dan tingkat penerimaan atau penolakan responden terhadap sesuatu. Pada penelitian ini film berisi kejadian yang dapat menggugah perasaan penonton misalnya dengan ditampilkannya tokoh yang memiliki penyakit kanker leher rahim, dan tokoh yang memiliki hasil tes IVA positif sehingga membuat responden sedih dan merasa takut jika mengalami hal yang serupa dengan kejadian pada film yang ditontonnya. Hal ini sesuai dengan teori yang menyebutkan bahwa isi pesan pada film dapat berpengaruh secara signifikan terhadap perasaan, emosi, tingkat penerimaan atau penolakan terhadap informasi yang diberikan (Nurseto, 2011).

Film pada penelitian ini memperlihatkan latar belakang yang sama dengan latar belakang responden misalnya lingkungan tempat tinggal, pekerjaan, paritas, dan alasan masyarakat di lokasi penelitian yang tidak mau ikutserta pada tes IVA. Lingkungan tempat tinggal responden merupakan lingkungan dengan geografis pesawahan karena Kabupaten Karawang merupakan salah satu Kabupaten Agraris dengan sebagian besar pekerjaan penduduknya adalah petani. Rata-rata paritas penduduk adalah 2-3 anak sesuai dengan angka dengan angka Total Fertility Rate Kabupaten Karawang. Selain itu latar belakang film ini 
juga disesuaikan dengan hasil wawancara dari Kepala Bagian Penyakit tidak menular Dinas Kesehatan Kabupaten Karawang pada saat $s t u d y$ pendahuluan penelitian yaitu salah satu faktor yang mengakibatkan ibu tidak menjalani tes IVA diantaranya adalah adanya sikap yang kurang baik seperti malu untuk memeriksakan diri, merasa tidak perlu memeriksakan diri dan merasa tes IVA tidak penting. Hal ini sesuai dengan teori menyebutkan bahwa pendidikan kesehatan yang menampilkan gambaran latar belakang yang serupa akan membuat responden lebih tertarik dan merasa mengalaminya. Pengalaman pribadi yang serupa dapat mempengaruhi sikap seseorang karena meninggalkan kesan yang kuat dan melibatkan faktor emosional (Notoatmodjo, 2007). Hal ini sesuai dengan respon responden pada saat pemberian pendidikan kesehatan melalui film, responden merasa tertarik dan menonton film tersebut sampai selesai karena merasa cerita film sesuai dengan pengalaman yang dialami oleh responden, selain itu pada saat diskusi responden aktif bertanya karena ketertarikan mereka terhadap cerita film yang serupa dengan pengalaman pribadi, responden merasa takut cerita pada film dapat terjadi pada mereka.

Kelebihan dari pendidikan kesehatan melalui film lainnya adalah film dapat diberikan berulang-ulang dengan durasi yang pendek. Media ini membuat pendidikan kesehatan lebih menarik dan tidak monoton. Pada penelitian ini film diberikan dengan durasi waktu 15 menit, sesuai dengan hasil penelitian Hubeis (2007), yang menyatakan bahwa durasi video sekitar 15 menit merupakan media yang efektif. Hal tersebut dapat membuat responden pada kelompok yang diberikan pendidikan kesehatan melalui film tidak mudah bosan dan tertarik untuk memperhatikan informasi yang diberikan. Selain itu pada penelitian ini film berisi penjelasan dari narasumber ahli dan testimoni dari ibu yang telah melakukan tes IVA untuk memberikan pengaruh kepada sikap ibu. Hal ini sesuai dengan teori yang menyebutkan bahwa sikap dapat terbentuk melalui bermacam-macam cara antara lain melalui peniruan pada orang lain, dan melalui sugesti yang diakibatkan dari pengaruh orang lain atau sesuatu yang mempunyai wibawa dalam pandangannya. Melalui film responden dapat dapat memperoleh informasi dari ahli-ahli atau spesialis dengan alat perekam (Nurseto, 2011). Hal ini sesuai dengan situasi yang terjadi pada saat penelitian dilakukan, setelah responden mengikuti alur cerita pada film, responden tertarik untuk mendengar penjelasan narasumber sehingga dapat meningkatkan sikap responden terhadap tes IVA.

Pada penelitian ini film berisi tambahan informasi berupa film animasi selain film cerita untuk menambah kejelasan informasi mengenai kanker serviks dan pentingnya tes IVA. Film dapat mengkongkritkan konsep-konsep yang abstrak dan dapat menghadirkan objek-objek yang sukar didapat pada lingkungan belajar. Dengan adanya animasi maka konsep tentang kanker serviks yang masih abstrak dapat menjadi lebih nyata. Pada saat penelitian dilakukan responden pada kelompok yang diberikan pendidikan kesehatan melalui film terlihat lebih serius memperhatikan penjelasan yang diberikan melalui animasi setelah mereka menonton cerita film. Hal ini sejalan pula dengan hasil penelitian Saguni (2006), yang menyatakan bahwa proses belajar mengajar dengan menggunakan narasi dan animasi merupakan media yang menarik dan terbukti cukup efektif untuk meningkatkan hasil belajar. Sesuai pula dengan hasil penelitian Hubeis (2007) dan Ambarwati (2014), yang menyatakan bahwa unsur kemasan video yang menampilkan banyak gambar dan warna dapat memperjelas informasi dan mempermudah penghayatan seseorang terhadap informasi tersebut. Oleh karena itu, kejelasan informasi yang diberikan melalui film dapat meningkatkan sikap ibu pada tes IVA.

Penelitian ini memiliki keterbatasan penelitian yaitu penelitian ini menggunakan desain pre-post test one group sehingga peneliti tidak dapat membandingkan hasil pendidikan kesehatan antara kelompok responden yang diberikan pendidikan kesehatan melalui film dan kelompok responden yang tidak diberikan pendidikan kesehatan melalui film. Selain itu penelitian ini merupakan penelitian kuantitatif sehingga tidak dapat menggali faktor sikap dan niat secara lebih mendalam lagi. Penelitian ini juga tidak mengukur faktor lain yang dapat 
mempengaruhi pendidikan kesehatan misalnya dukungan keluarga, budaya. Keterbatasan penelitian lain adalah peneliti tidak dapat mengontrol berapa kali dan berapa lama responden menonton DVD.

\section{Penutup}

Berdasarkan hasil penelitian dapat dibuat simpulan bahwa terdapat pengaruh positif pendidikan kesehatan melalui film terhadap sikap, niat ibu dan keikutsertaan ibu pada tes IVA di Kabupaten Karawang. Saran teoritis pada penelitian ini adalah diperlukan penelitian lebih lanjut dengan menggunakan desain randomized controlled trial, penggunaan desain kualitatif dan diperlukan penelitian lebih lanjut pada variabel lainnya yang dapat mempengaruhi pendidikan kesehatan melalui film misalnya budaya, dukungan keluarga. Sedangkan saran praktis pada penelitian ini adalah diharapkan pendidikan kesehatan melalui film dapat digunakan sebagai salah satu metode yang dilakukan pada program See and Treat di Kabupaten Karawang dan diharapkan pelaksanaan pemeriksaan tes IVA lebih memperhatikan privacy masyarakat sehingga dapat mengatasi keengganan masyarakat untuk menjalani tes IVA yang diakibatkan adanya rasa malu.

\section{Daftar Pustaka}

Ackerson, K. 2007.Factors Influencing Cancer Screening Practices of Underserved Women. Journal of The American Academy of Nurse Practitioners, 19(11):591-601.

Ambarwati, dkk. 2014. Media Leaflets, Video and Knowledge Elementary School of Smooking. Jurnal Kesehatan Masyarakat, 10 (1):7-13.

Arbyn, M. 2008. Pooled Analysis Of The Accuracy Of Five Cervical Cancer Screening Tests Assessed in Eleven Studies in Africa and India. International Journal of cancer, 23:15360.

Dinas Kesehatan Kabupaten Karawang. 2013. Laporan Tahunan Kegiatan Pelayanan IVA di Kabupaten Karawang Tahun 2013.

Gayatri, D.B; Nurachmah, E. 2005. Peluang Ketahanan Hidup 5 Tahun Pasien Kanker Serviks di RSUPN Dr Cipto Mangunkusumo dan RS. Kanker Dharmais Jakarta. Jurnal Keperawatan Indonesia, 7(1):1-5.

Ghazali, F; Hanum; JHPIEGO. 2009. Cervical
Cancer Prevention Program with Visual Inspection with Acetat Acid (VIA) in Twelve Facilities in Karawang District. Indonesian Journal of Cancer, 3(3):91-5.

Handayani,L.R. 2010. Pengaruh Model Pembelajaran Kesehatan Menggunakan Multimedia terhadap Perubahan Pengetahuan dan Sikap siswa SLTP terkait Faktor Resiko Penyakit Jantung Koroner. Buletin Penelitian Sistem Kesehatan, 13(4):1-10.

Hubeis. 2007. Pengaruh Desain Pesan Video Instruksional Terhadap Peningkatan Pengetahuan Petani Tentang Pupuk Agrodyke. Jurnal Agro Ekonomi, 25(1):1-10.

IARC. 2012. Globocan 2012 : Estimated Cancer Incidence, Mortality and Prevalence Worldwide in 2012. WHO

Krawcyzk, A. 2012. How to Inform: Comparing Writen and Video Education Interventions to Increase Human Papilomavirus Knowledge and Vaccination Intentions in Young Adults. Journal of American College Health, 60(4):110

Leyva, M; Tarwater, P. 2006. Attitudes Towards Cervical Cancer Screening: A Study of Beliefs Among Women In Mexico Californian. Journal of Health Promotion, 4(2):13-24.

$\mathrm{Lu}-\mathrm{Lu}$, et al. 2012. Population Based Study on The Prevalence and Risk Factors for Human Papilloma Virus Infection in Quijing of Yunnan Province, Southwest China. Virology Journal, 9(153):1-8

Montano, E; Kasprzyk. 2008. Theory Of Reasoned Action. Dalam: Glanz, K; Rimer K; Viswanath. Health Behavior and Health Education Theory Reserch and Practice. 4, editor. San Francisco: Jossey-Bass, 68-80.

Musfiroh, M; Lukmanawati, B; Wisudaningtyas. 2014. Penyuluhan Terhadap Sikap Ibu dalam Memberikan Toilet Training Pada Anak. Jurnal Kesehatan Masyarakat, 9 (2):157-166.

Notoatmodjo, S. 2007. Promosi kesehatan dan Ilmu Perilaku. 1, editor. Jakarta: Rineka Cipta, 1-247.

Ngan, Y.S.H. 2011. Asia Oceania Guidelines For The Implementation Of Program for Cervical Cancer Prevention and Control. Journal of Cancer Epidemiology.1(1):1-24

Nurseto.2011. Membuat Media Pembelajaran yang Menarik. Jurnal Ekonomi dan Pendidikaan, 8(1):19-34.

Peirson, L; Donna; Warren, C. 2013. Screening For Cervical Cancer: a Systematic Review and Meta-Analysis. Biomed Central Journal, 2(13):1-14.

Poureslami, I; Balka, E. 2007. Assessing the 
Effectiveness of Informational Video Clips on Iranian Immigrants' Attitudes Toward and Intention to Use the BC HealthGuide Program in the Greater Vancouver Area. Medscape General Medicine Journal, 9(1):112.

Putri, P.K.D. 2009. Pengaruh Tingkat Pendidikan, Pengetahuan, Sikap dan Terpaan Iklan Layanan Masyarakat KB Versi Shireen
Sungkar dan Teuku Wisnu di TV terhadap Perilaku KB pada Wanita atau Pria dalam Usia Subur. Jurnal Interaksi, 1(1):1-11.

Sugiarsi, S. 2011. Pendidikan Kesehatan Pada Kelompok Ibu PKK Dalam Meningkatkan Pemahaman Masyarakat Untuk Mencegah Penyakit Kanker Serviks. Jurnal Maternal, 4:108-12. 